\title{
Diet and food consumption of the pearl cichlid Geophagus brasiliensis (Teleostei: Cichlidae): relationships with gender and sexual maturity
}

\author{
Rodrigo F. Bastos ${ }^{1}$, Mário V. Condini ${ }^{1}$, Antonio S. Varela Junior ${ }^{2}$ and \\ Alexandre M. Garcia ${ }^{1}$
}

Despite the importance of the pearl cichlid Geophagus brasiliensis for the aquarium fish trade worldwide and its wide distribution, many aspects of its biology, such as the relationships between its feeding ecology and reproductive behavior, are not fully understood in natural conditions on its native habitat. In this paper, we investigated its diet focusing on how differences in diet and food consumption are related to differences in gender and sexual maturity. The digestive tract of each individual was dissected and had its content analyzed, whereas each gonad was microscopically analyzed to determine gender (male/female) and sexual maturity (immature/mature). A total of 28 females and 31 males were analyzed. Mature individuals were more common than immature specimens both for males $(64.50 \%)$ and females $(64.30 \%)$. The analysis of 52 individuals with non-empty digestive tracts revealed a diet comprised of 27 items. According to the Index of Alimentary importance (\%IAi), the most important food items in the diet were Gastropoda (37.30\%), fragments of vascular plants (15.16\%), detritus (10.14\%), Amphipoda (9.24\%), and fish scales (6.29\%). Mature males had more empty stomachs (65.00\%) when compared to immature males (27.27\%) and immature $(55.56 \%)$ and mature females $(40.00 \%)$. Also, mature females seemed to have more food consumption (greater mean values of total volume) in their digestive tracts than mature males. Some hypotheses are proposed in order to distinguish if this gender-based difference in food consumption in mature individuals of the pearl cichlid could be associated with the development of primary and secondary sexual characteristics or with asymmetrical time invested in parental care activities.

Apesar da sua ampla distribuição e importância para o comércio aquariofilista, muitos aspectos da biologia do cará Geophagus brasiliensis no seu habitat natural, como a relação entre sua ecologia alimentar e comportamento reprodutivo, ainda não são bem conhecidos. Nesse trabalho foi investigada sua dieta, enfocando como as diferenças na dieta e no consumo alimentar estão relacionadas ao sexo (macho/fêmea) e a maturidade (imaturo/maturo). O trato digestório de cada indivíduo foi dissecado e teve seu conteúdo analisado, enquanto cada gônada foi analisada microscopicamente para determinar o sexo e a maturidade. Um total de 28 fêmeas e 31 machos foram analisados. Indivíduos maturos foram mais comuns do que espécimes imaturos, tanto para machos $(64,50 \%)$ quanto para fêmeas $(64,30 \%)$. A análise de 52 indivíduos com alimento no trato revelou uma dieta composta por 27 itens. De acordo com o Índice de Importância Alimentar (\%IAi), os itens alimentares mais importante na dieta foram Gastropoda (37,30\%), fragmentos de plantas vasculares (15,16\%), detrito (10,14\%), Amphipoda (9,24\%) e escamas de peixe (6,29\%). Machos maturos tiveram mais estômagos vazios $(65,00 \%)$ quando comparados com machos imaturos $(27,27 \%)$ e fêmeas imaturas $(55,56 \%)$ e maturas $(40,00 \%)$. Além disso, fêmeas maturas apresentaram maior consumo de alimentos (valor médio do volume total de alimentos) do que machos maturos. Algumas hipóteses são propostas na tentativa de explicar se essa diferença no consumo de alimento entre machos e fêmeas maturos está relacionada ao desenvolvimento de caracteres sexuais primários e secundários, ou com a assimetria na quantidade de tempo empregado em atividades relacionadas ao cuidado parental.

Key words: Feeding ecology, Parental care, Patos-Mirim lagoon complex, Reproduction.

\section{Introduction}

One of the most emblematic species among Neotropical fishes is the pearl cichlid Geophagus brasiliensis (Quoy \& Gaimard, 1824), which has high commercial value in the aquarium fish trade worldwide due to its beautiful coloration (Innes, 1954). The pearl cichlid has a wide distribution range along the coastal drainages of eastern and southern Brazil and Uruguay, occurring in an array of aquatic systems like streams (Uieda, 1983; Sabino \& Castro, 1990), ponds (Vono

${ }^{1}$ Universidade Federal do Rio Grande (FURG), Instituto de Oceanografia, Laboratório de Ictiologia, Campus Carreiros, Base Oceanográfica. Av. Itália km 8, Bairro Carreiros, Caixa Postal 474, 96201-900, Rio Grande, RS, Brazil.rfbastos@furg.br(RFB); amgarcia@mikrus.com.br(AMG) ${ }^{2}$ Universidade Federal do Rio Grande (FURG), Laboratório de Histologia, Instituto de Ciências Biológicas, Campus Carreiros, Prédio 6. Av. Itália km 8, Bairro Carreiros, 96201-900, Rio Grande, RS, Brazil. 
\& Barbosa, 2001), flood plains (Meschiatti, 1995), coastal lagoons (Aguiaro \& Caramaschi, 1995; Loebmann \& Vieira, 2005), and also in estuaries (Chao et al., 1985; Garcia et al., 2003). It has been reported to occur in different sites along the Patos-Mirim lagoon complex $(14,000 \mathrm{~km})$ in southern Brazil such as the São Gonçalo channel connecting Mirim and Patos lagoons (Burns et al., 2006), in lakes and wetlands of the Taim Ecological Reserve (Garcia et al., 2006), and in the estuarine zone of Patos Lagoon (Garcia et al., 2003).

However, despite its importance for the aquarium fish trade worldwide and its wide distribution, many aspects of its biology, such as the relationships between its feeding ecology and reproductive behavior, is not understood in natural conditions on its native habitat. Cichlids exhibit a diverse array of feeding and reproductive adaptations that can change across sex and body size. Most part of the Geophagine display some kind of parental care, including guarding the eggs in a nest or substrate or brooding them in their mouth (Barlow, 2000). In many cases, parental care is associated with reduction in foraging and also with the percentage of empty stomachs (PES) (Arrington et al., 2002). Species with high PES feed less often than species that have lower PES values (Arrington et al., 2002; Vinson \& Angradi, 2011). If there are differences in time spent on parental care by male and females, it is plausible to hypothesize that would occur differences on foraging and food consumption between genders. Currently, no prior studies had investigated the relationships between diet and reproductive aspects of the pearl cichlid in order to evaluate this hypothesis.

Previous studies on the diet of G. brasiliensis have shown that the pearl cichlid is an omnivorous fish preying mainly upon crustaceans, insects and plant matter (Nomura \& Carvalho, 1972; Uieda, 1983; Sabino \& Castro, 1990; Abelha $\&$ Goulart, 2004). However, up to our knowledge, no published study has directly investigated the relationships between diet and reproductive aspects of wild pearl cichlid populations. In this paper we investigated the feeding ecology of $G$. brasiliensis occurring in a subtropical lagoon complex, focusing on how differences in diet composition, food consumption and PES are related to differences in gender and sexual maturity.

\section{Material and Methods}

\section{Field collections}

Specimens were obtained from the database of two sites of the Brazilian Long Term Ecological Research (B-LTER) program that have been monitoring, since 1999, the ichthyofauna at the Taim Hydrological System (site 7) (Motta Marques et al., 2002) and Patos Lagoon and its estuarine zone (site 8) (Seeliger \& Odebrecht, 2010). These ecosystems are connected via a $75 \mathrm{~km}$ long natural channel locally know as São Gonçalo (Fig. 1a-b). Individuals analyzed in this study were collected with beach seine hauls in the shallow waters $(<1.5 \mathrm{~m})$ of four locations along the Patos-Mirim lagoon complex (Fig. 1b) on Autumn (March, April, and May) and Winter (July) of 2004, and on Summer (December, January, and February) of 2004-2005. The beach seine was $9 \mathrm{~m}$ long and $1.8 \mathrm{~m}$ high, with $13 \mathrm{~mm}$ mesh in the wings and $5 \mathrm{~mm}$ in the center and bag. Individuals were fixed in the field with $10 \%$ formaldehyde. Multidimensional scaling (MDS) analysis based on a presence/absence matrix (binary data) and the Bray-Curtis similarity index did not reveal differences in diet composition among site collections (stress: $0.19)$. Therefore, we pooled our dataset for the subsequent data analysis of diet and food consumption in relation to gender and sex maturation.

\section{Sampling processing and data analyses}

In laboratory, each individual had its total length (TL, $\mathrm{mm}$ ) and weight $(\mathrm{g})$ measured. After, they had their digestive tract and gonads dissected, which were later preserved in $70^{\circ} \mathrm{GL}$ alcohol for analysis of food content and reproductive aspects (sex determination and sexual maturity), respectively. Using a stereoscopic binocular microscope, each food item found in the digestive tract was identified to the lowest taxonomic level possible based on the literature (Thorp \& Covich, 2001; Voshell, 2002; Ruppert \& Barnes, 2003).

Sex determination and sexual maturity were obtained based on the histological analysis of the gonads. After been removed from each specimen, gonads were fixed in $4 \%$ paraformaldehyde solution for $24 \mathrm{~h}$. After fixation, gonads were dehydrated in successive concentrations of alcohol $70 \%, 80 \%$, $90 \%$, and two $100 \%$ baths for 20 min each. Then, they were diafanated in two xylene bath (10 min each), infiltrated in two Paraplast X-tra bath (sigma P-3808) (15 min each), and finally included on Paraplast X-tra. After, gonads were microtomized transversely at $4 \mu \mathrm{m}$ and stained with hematoxylin-eosin (2) and Mallory's Trichrome (2). Gender and sexual maturity were determined by the analysis of the sections under an optical microscope (BX51 - Olympus) under increase of up to 100X, considering the typical morphology for each stage of development of oogonia and spermatogonia. The ovaries were assigned a stage based on the most advanced stage of oocyte

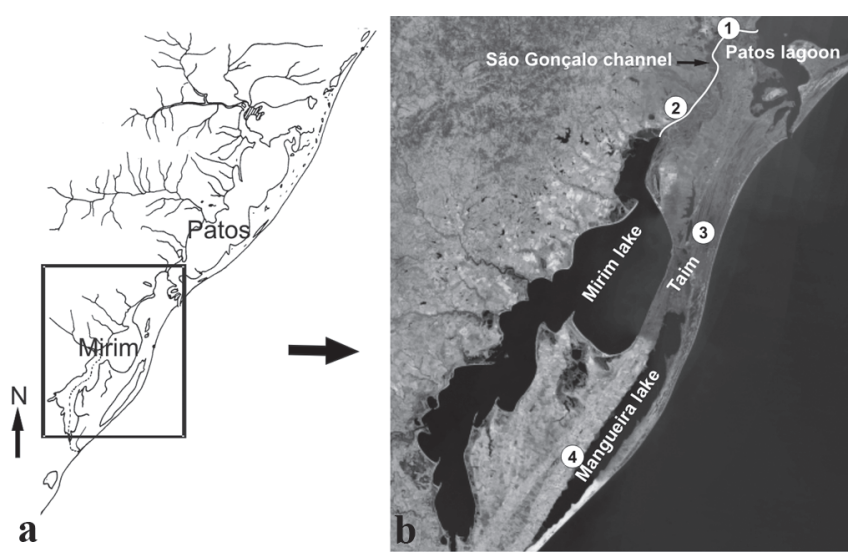

Fig. 1. Coastal plain of Rio Grande do Sul in southern Brazil showing the Patos-Mirim lagoon complex (a) and the location of the four sampling sites where the specimens of the pearl cichlid Geophagus brasiliensis were collected (b). 
development, namely perinucleolar, cortical alveolar vitellogenic, hyalinized or nucleus breakdown; whereas the testis were classified based on the stage of cists (spermatogonia, spermatocyte, spermatid, or spermatozoon).

As a proxy for the relative abundance of each prey found, we calculated the area $\left(\mathrm{mm}^{2}\right)$ occupied by each item with graph paper. In order to calculate the area, each item was spread evenly over the Petri dish with no empty space between them and with a standard height of $1 \mathrm{~mm}$. In case of an item with height greater than $1 \mathrm{~mm}$, the item was broken down in smaller pieces in order to maintain the standard height of $1 \mathrm{~mm}$. (Hellawell \& Abel, 1971). When a food item was smaller than $1 \mathrm{~mm}$ high, its height was measured. We computed the volume (V) based on the area occupied by the item and its height (area $\mathrm{x}$ height). This parameter (V) was expressed in percentage $(\% \mathrm{~V})$ when calculating the Alimentary Index (IAi) (see below). Additionally, we calculated the frequency of occurrence (expressed in percentage, $\% \mathrm{~F}$ ) for each item found in the digestive tract using the formula: $\% \mathrm{~F}=\mathrm{N}_{\text {to }} / \mathrm{N}_{\text {ta }} \times 100, \mathrm{~N}_{\text {to }}$ $=$ number of tracts in which the item occurred and $\mathrm{N}_{\mathrm{ta}}=$ number of tracts analyzed (Hyslop, 1980).

We also employed the Alimentary Index (IAi) proposed by Kawakami \& Vazzoler (1980) to compare the diet between gender (male/female) and sexual maturity (immature/mature) groups. This index takes into account not only the $\% \mathrm{~F}$, but also the volume occupied by the item. The IAi was calculated using the formula: $\% \mathrm{IAi}=\% \mathrm{~F} * \% \mathrm{~V} / \Sigma(\% \mathrm{~F} * \% \mathrm{~V}) * 100$, where the $(\% \mathrm{~F} * \% \mathrm{~V})$ of an item was divided by the sum $(\% \mathrm{~F} * \% \mathrm{~V})$ of all items. We estimated how many fish were feeding (food consumption) between genders (male/female) and sexual maturity (immature/mature) based on the percentage of fish in the sample with empty stomachs (PES) (Vinson \& Angradi, 2011). Two-way ANOVA was employed to evaluate differences in the average values of food consumption $\left[\log _{10}(\right.$ Volume +1$\left.)\right]$ in relation to gender (with 2 levels: male/female) and sexual maturity (with 2 levels: immature/mature). ANOVA's assumptions of normality and homogeneity of variance were assessed via the Kolmogorov-Smirnov and Cochran tests, respectively (Zar, 1994).

\section{Results}

We analyzed 69 individuals with size ranging from 30 to $255 \mathrm{~mm}$ TL, from which, 59 individuals had their gonads microscopically examined. This analysis revealed 28 females and 31 males, with sizes ranging from 50 to $248 \mathrm{~mm}$ TL (mean= $137.5, \mathrm{SD}=65.7$ ) and from 49 to $265 \mathrm{~mm} \mathrm{TL}$ (mean=141, $\mathrm{SD}=$ 65.7 ), respectively. Mature individuals were more common than immature specimens both for males $(64.5 \%)$ and females $(64.3 \%)$. The percentage of mature individuals analyzed were higher during warmer months both for male ( $45.45 \%$ in Autumn and $70.59 \%$ in Summer) and female (20\% in Autumn and 58.33\% in Summer). Only four individuals were analyzed during Winter (3 mature male and 1 immature female).

The inspection of the individuals with food content in their digestive tract $(\mathrm{n}=52)$ revealed a diet comprised of 27 food items of animal and vegetal origins (Table 1). According to the \%IAi, the five most important broad food categories in the diet were Mollusca (38.37\%), vascular plants (21.99\%), Crustacea (21.92\%), detritus (6.58\%), and Osteichthyes $(6.13 \%)$ (Table 1). When considering lower taxonomic levels, the most important food items in the diet were Gastropoda $(37.3 \%)$, fragments of vascular plants $(15.16 \%)$, detritus (10.14\%), Amphipoda (9.24\%), and fish scales (6.29\%). Gastropoda and Ostracoda were the food items with highest contribution in volume to the diet $(39.95 \%$ and $9.30 \%$, respectively), whereas plant fragments $(40.38 \%)$, amphipoda (40.38\%), fish scales (32.69\%), Diptera (30.77\%) and seeds (28.85) had higher contribution in terms of frequency of occurrence (\%F) (Fig. 2).

It was possible to observe some differences in the diet composition according to gender and sexual maturity (Table 1). For instance, regarding immature individuals, males consumed more amphipod (32.73\%) than females (0.93\%), whereas an opposite pattern occurred for gastropods, which were consumed more heavily by females (39.65\%) than males (1.7\%). Gastropods consumption also varied among mature individuals, with almost two-fold difference in the IAi values between males (40.64\%) and females (22.52\%) (Table 1).

The PES showed that $43.48 \%$ of the all analyzed individuals $(\mathrm{n}=69)$ had empty stomachs. Among groups, mature males had more empty stomachs $(65.00 \%)$ when compared to immature males (27.27\%) and immature (55.56\%) and mature females (40\%) (Fig. 3a). Although large variance around mean values precluded statistical significance $(p>0.05)$, mature females seemed to have greater mean values of food consumption (express in $\% \mathrm{~V}$ ) in their tract than mature males (Fig. 3b).

\section{Discussion}

Both animal and plant material contributed to the diet of the pearl Cichlid in the present study, which is in consonance with the omnivorous feeding mode usually assigned for the species (Nomura \& Carvalho, 1972; Uieda, 1983; Sabino \& Castro, 1990; Abelha \& Goulart, 2004). According to Sabino $\&$ Castro (1990), such feeding mode is corroborated by the morphology of the digestive tract that shows a high ratio between the digestive tube and the fish standard length, which would indicates an adaptation to process hard to digest food like plant material.

Mollusks, vascular plants, crustaceans, and detritus constituted the main food categories in the diet of the pearl cichlid in the present study. Although these broad food categories have also been reported as important in the diet of this species elsewhere, there are noticeable differences among such studies. For instance, in our present study we found that gastropods, vascular plants, detritus, amphipods, and fish scales were the most important food items in the pearl cichlid's diet, whereas other studies reported diptera and cladocera (Uieda, 1983), detritus (Oliveira \& Bennemann, 2005), detritus and aquatic invertebrates (Loureiro-Crippa \& Hahn, 2006), rotifera and algae (Dias et al., 2005), insects (Gomiero \& Braga, 
Table 1. Food items found in the digestive tracts of the Pearl cichlid Geophagus brasiliensis. The number of individuals with food in the digestive tracts or not (empty) are represented in bold. The Index of Alimentary importance (\%IAi) values represent the alimentary importance of each item. Asterisks $(*)$ denote values $<0.01$.

\begin{tabular}{|c|c|c|c|c|c|c|c|}
\hline & \multicolumn{7}{|c|}{ IAi } \\
\hline & \multirow[b]{2}{*}{ General } & \multicolumn{3}{|c|}{ Immature } & \multicolumn{3}{|c|}{ Mature } \\
\hline & & Female & Male & Both & Female & Male & Both \\
\hline Empty digestive tracts (n) & 17 & 4 & 2 & 6 & 1 & 7 & 8 \\
\hline Digestive tracts with food items (n) & 52 & 14 & 9 & 23 & 9 & 13 & 22 \\
\hline Insecta (terrestrial stages) & 0.38 & & 0.30 & 0.05 & 0.80 & 0.99 & 1.06 \\
\hline Hymenoptera & * & & 0.24 & 0.04 & & & \\
\hline Unidentified terrestrial insect & 0.68 & 0.35 & 0.43 & 0.06 & & 0.08 & 1.68 \\
\hline Crustacea & 21.92 & 7.94 & 20.62 & 12.72 & 40.66 & 15.73 & 23.58 \\
\hline Amphipoda & 9.24 & 0.93 & 32.73 & 8.23 & 3.04 & 1.76 & 2.45 \\
\hline Cladocera & $*$ & & & & 0.05 & & $*$ \\
\hline Copepoda & 3.62 & 5.35 & 0.11 & 4.00 & & 2.02 & 0.90 \\
\hline Decapoda & & 0.22 & & 0.10 & 0.90 & 0.76 & 0.90 \\
\hline Ostracoda & 3.47 & 15.84 & 15.94 & 18.74 & & & \\
\hline Unindentified crustacean & 3.19 & 0.05 & 1.59 & 0.42 & 26.40 & 0.95 & 6.21 \\
\hline Mollusca & 38.37 & 55.38 & 31.52 & 47.03 & 16.05 & 38.44 & 30.01 \\
\hline Bivalvia & 0.25 & 0.92 & 0.11 & 0.85 & & 0.04 & 0.02 \\
\hline Gastropoda & 37.30 & 39.65 & 1.70 & 25.53 & 22.52 & 40.64 & 35.55 \\
\hline Insecta (aquatic stages) & 4.54 & 3.36 & 5.48 & 4.25 & 1.41 & 8.60 & 6.23 \\
\hline Coleoptera & 0.02 & & & & & 0.21 & 0.10 \\
\hline Diptera & 2.17 & 1.79 & 3.28 & 3.16 & 1.98 & 2.17 & 2.42 \\
\hline Ephemeroptera & $*$ & & 0.48 & 0.07 & & & \\
\hline Trichoptera & 1.34 & 0.11 & 1.87 & 0.58 & & 4.92 & 2.19 \\
\hline Unidentified aquatic insect & 0.17 & & 0.40 & 0.56 & 1.13 & 1.58 & 0.03 \\
\hline Osteichythyes & 6.13 & 0.09 & 10.90 & 2.21 & 9.31 & 12.14 & 11.78 \\
\hline Fin & 0.45 & & 2.13 & 0.31 & 1.49 & 0.14 & 0.49 \\
\hline Gobiidae & 0.09 & & & & & 0.82 & 0.36 \\
\hline Scale & 6.29 & 0.16 & 9.35 & 2.07 & 9.35 & 11.15 & 11.66 \\
\hline Spine & 0.02 & & 0.43 & 0.06 & & * & * \\
\hline Aracnida & 0.01 & 0.03 & * & 0.02 & & * & * \\
\hline Hidracarina & 0.02 & 0.05 & 0.02 & 0.04 & & * & * \\
\hline Annelida & * & * & & * & & & \\
\hline Oligochaeta & * & $*$ & & * & & & \\
\hline Vascular plants & 21.99 & 27.94 & 27.58 & 29.37 & 24.65 & 17.05 & 19.46 \\
\hline Flower & 0.59 & 4.87 & 0.48 & 3.16 & & & \\
\hline Leave & 0.25 & 0.22 & 0.58 & 0.42 & & 0.32 & 0.14 \\
\hline Seed & 4.90 & 10.62 & 12.99 & 13.09 & 3.78 & & 1.02 \\
\hline Plant fragments & 15.16 & 11.51 & 10.04 & 12.38 & 19.37 & 21.15 & 21.40 \\
\hline Algae & 0.07 & & 1.12 & 0.17 & & & \\
\hline Diatomacea & 0.13 & & 2.39 & 0.35 & & & \\
\hline Detritus & 6.58 & 5.26 & 2.48 & 4.18 & 7.12 & 7.04 & 7.87 \\
\hline Detritus & 10.14 & 7.30 & 1.99 & 5.51 & 10.00 & 11.19 & 12.45 \\
\hline
\end{tabular}

2008), mollusks and seeds (Mazzoni \& Costa, 2007) as the main food items. Such discrepancies are probably related with the difficult to quantify with precision certain items, which can render over or underestimated values, especially when dietary indices are employed to describe the diet. Alternatively, such differences in the relative importance of food items could simply arise from differences in prey availability across study sites (Winemiller, 1989; Wootton, 1999). As pointed out by prior studies (Abelha \& Goulart, 2004; Mazzoni \& Costa, 2007), the pearl cichlid exhibit marked trophic plasticity and opportunism in prey consumption and, therefore, could exploit the most abundant prey available at each site.

Overall, we did not found marked differences in diet composition between genders (male/female) and sexual maturity (immature/mature) individuals. This general pattern is also reported by Nomura \& Carvalho (1972) that had investigated the relationships between the diet, gender and body size of the pearl cichlid. However, we observed differences in the amount of food consumed and percentage of empty stomach (PES) according to gender and sexual maturity. Mature females seemed to have higher amounts of food in their digestive tract when compared with mature males, and mature males had higher PES than mature males.

Such sex based differences in food consumption by mature individuals could be related with gender asymmetry in the energy invested in the development of primary and secondary sexual characteristics. At one hand, it can be hypothesized that females would consume more food than males in order to counterbalance their higher energetic investment in more energy-demanding gametes (eggs), compared to less energy-demanding gametes (sperms) produced by males. According to Meijide et al. (2005) that studied the cichlid Cichlasoma dimerus, ovaries can reach large sizes faster than testes, which had smaller sizes even in advance stages of maturation. At other hand, there are evidences that males invest large amounts of energy in the 


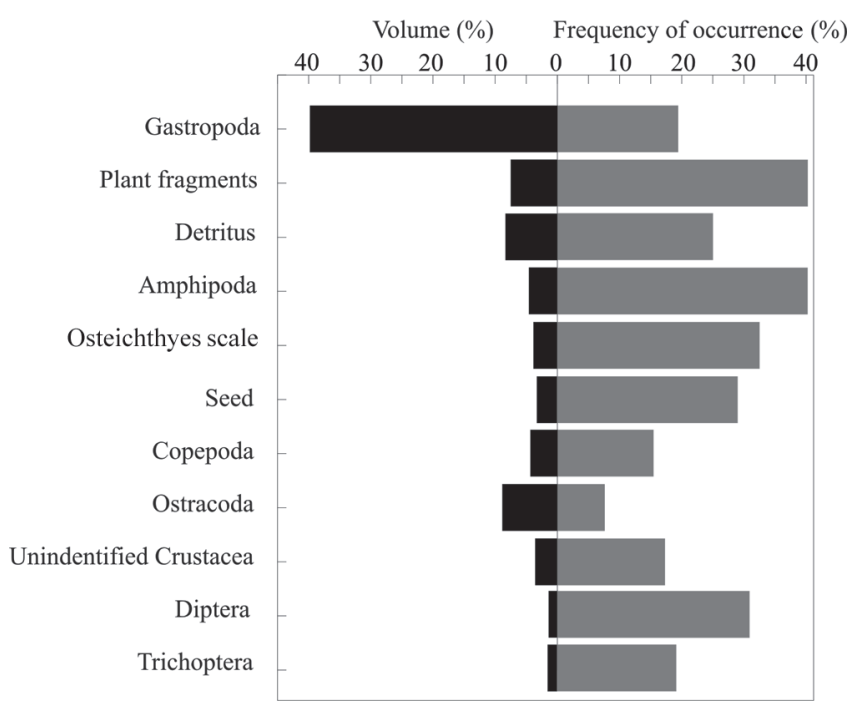

Fig. 2. Volume (\%, black bars) and frequency of occurrence (\%, gray bars) of the main food categories found in the digestive tracts of the pearl cichlid Geophagus brasiliensis.

development of secondary sexual characteristics during reproduction. For instance, during the mating season, the male develops a cephalic protuberance (rich in lipids) that apparently functions in female attraction, which disappears after the mating period (Chellappa et al., 2003).

Alternatively, the explanation for the differential food consumption between female and mature males could be related with parental care behavior. In order to be more successful in this behavior, pearl cichlid males invest more energy in growth, resulting in greater growth rates and larger body sizes than females (Nomura \& Carvalho, 1972). In cichlids, activities involved in parental care can span 3 to 4 weeks and can be extended weeks after the egg's eclosion, when parents protect their fry from predators (Keenleyside, 1991). Parental care behavior is not yet fully described for the pearl cichlid, especially regarding the role played by each sex in the different phases involved in parental care, like choosing the substrate, nest preparation, territory defense, nest guard and fry protection. Nevertheless, considering the assumption that time invested in the parental care activities is asymmetrical towards males, it is plausible to hypothesize that the lower food consumption (lower PES values) observed in mature males results from the fact that males spend more time guarding the nest and their fry than females and, consequently, have less time available for food foraging.

Future studies encompassing field and laboratory experiments would be necessary to evaluate the proposed hypothesizes in order to distinguish if differential food consumption in mature males and females of the pearl cichlid observed in the present study is associated with the development of primary and secondary sexual characteristics or with asymmetrical time invested in parental care activities.
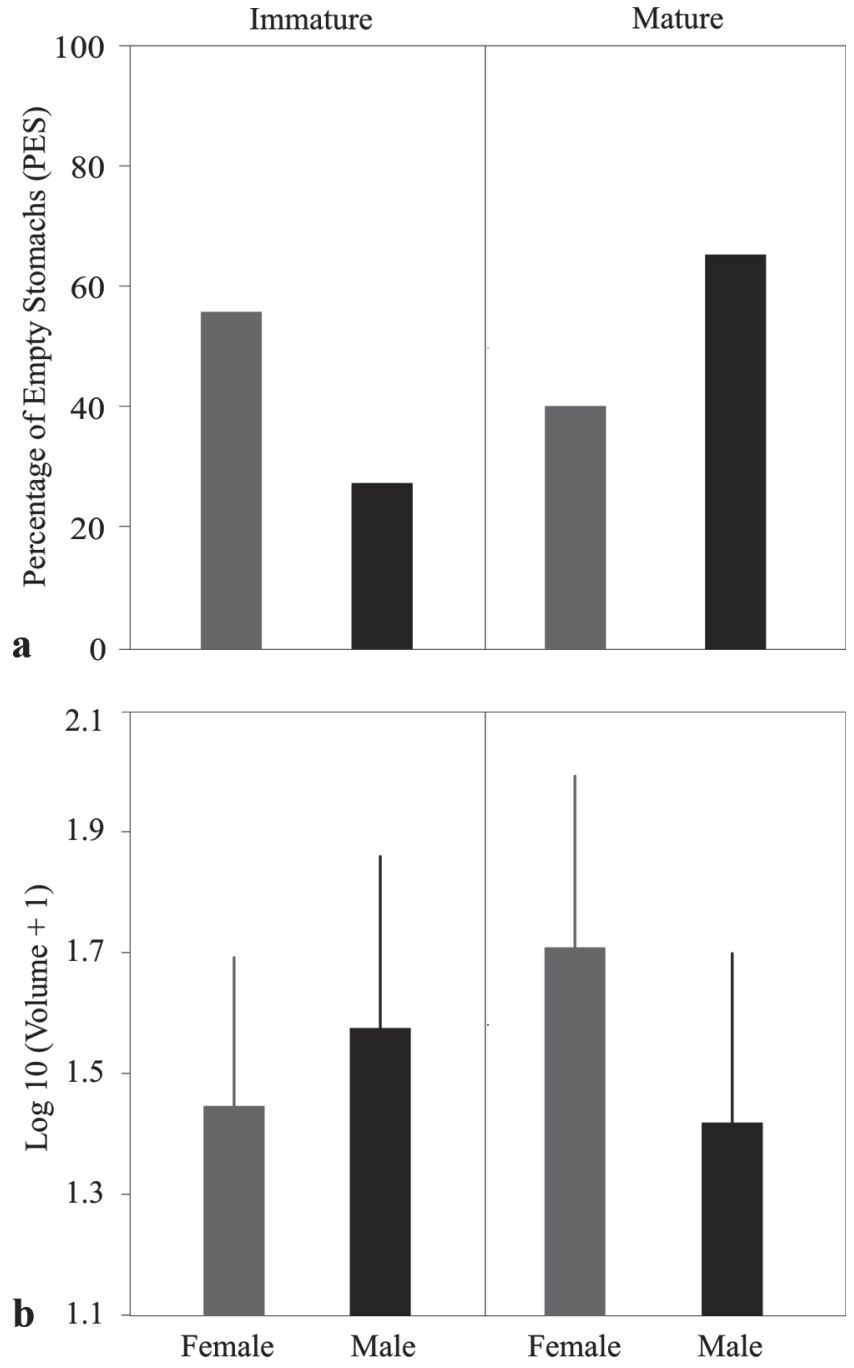

Fig. 3. a: Percentage of empty stomachs (PES) according to sexual maturity (immature and mature) and gender (female and male). b: Mean values ( + standard error) of the total food content expressed in volume $\left(\log _{10}(\mathrm{x}+1)\right.$ transformed $)$ in the digestive tract of the pearl cichlid Geophagus brasiliensis.

\section{Acknowledgements}

We thank colleagues of the Laboratório de Ictiologia, Instituto de Oceanografia, Universidade Federal do Rio Grande (FURG) who have assisted in the field collection and in the laboratory, especially Marlucy Claudino and Elisa Seyboth and also the technicians João Cassemiro and Maria Inês of the Laboratório de Histologia, Instituto de Ciências Biológicas (FURG). RFB thanks grant received from the Conselho Nacional de Desenvolvimento Científico e Tecnológico (CNPq) and financial and logistic support from the sites 7 (Taim) and 8 (Patos Lagoon) of the Brazilian Long-Term Ecological Studies program (PELD - 1999-2009). 


\section{Literature Cited}

Abelha, M. C. F. \& E. Goulart. 2004. Oportunismo trófico de Geophagus brasiliensis (Quoy \& Gaymard, 1824) no reservatório de Capivari, Estado do Paraná, Brasil. Acta Scientiarum. Biological Sciences, 26: 37-45.

Aguiaro, T. \& E. P. Caramaschi. 1995. Ichthyofauna composition of three coastal lagoons in the north of the state of Rio de Janeiro (Brazil). Arquivos de Biologia e Tecnologia, 38: 1181-1189.

Arrington, D. A., K. O. Winemiller, W. F. Loftus \& S. Akin. 2002. How often do fishes "run on empty"? Ecology, 83: 2145-2151.

Barlow, G. W. 2000. The cichlid fishes. Cambridge, Massachusetts, Perseus publishing, 335p.

Burns, M. D. D. M., A. M. Garcia, J. P. Vieira, M. A. Bemvenuti, D. M. L. Motta Marques \& V. Condini. 2006. Evidence of habitat fragmentation affecting fish movement between the Patos and Mirim coastal lagoons in southern Brazil. Neotropical Ichthyology, 4: 69-72.

Chao, L. H., L. E. Pereira \& J. P. Vieira. 1985. Estuarine fish community of the dos Patos Lagoon, Brazil. A baseline study. Pp. 429-450. In: Yanez-Arancibia, A. (Ed.). Fish Community Ecology in Estuaries and Coastal Lagoons: Towards an Ecoystem Integration. Mexico, DR (R) UNAM Press, 653p.

Chellappa, S., M. R. Camara \& N. T. Chellappa. 2003. Ecology of Cichla monoculus (Osteichthyes: Cichlidae) from a reservoir in the semi-arid region of Brazil. Hydrobiologia, 504: 267-273.

Dias, A. C. M. L., C. W. C. Branco \& V. G. Lopes. 2005. Estudo da dieta natural de peixes no reservatório de Ribeirão das Lajes, Rio de Janeiro, Brasil. Acta Scientiarum, Biological Sciences, 27: 355-364.

Garcia, A. M., M. A. Bemvenuti, J. P. Vieira, D. M. L. Motta Marques, M. D. M. Burns, A. Moresco \& M. V. Condini. 2006. Checklist comparison and dominance patterns of the fish fauna at Taim Wetland, South Brazil. Neotropical Ichthyology, 4: 261-268.

Garcia, A. M., M. B. Raseira, J. P. Vieira, K. O. Winemiller \& A. M. Grimm. 2003. Spatiotemporal variation in shallow-water freshwater fish distribution and abundance in a large subtropical coastal lagoon. Environmental Biology of Fishes, 68: 215-228.

Gomiero, L. M. \& F. M. S. Braga. 2008. Feeding habits of the ichthyofauna in a protected area in the state of São Paulo, southeastern Brazil. Biota Neotropica, 8: 1-8.

Hellawell, J. M. \& R. Abel. 1971. A rapid volumetric method for the analysis of the food of fishes. Journal of Fish Biology, 3: 29-37.

Hyslop, E. J. 1980. Stomach contents analysis - a review of methods and their application. Journal of Fish Biology, 17: 411-429.

Innes, W. T. 1954. Exotic Aquarium Fishes: A Work of General Reference, $17^{\text {th }}$ ed. Philadelphia, Innes publishing company, 533p.

Kawakami, E. \& G. Vazzoler. 1980. Método gráfico e estimativa de índice alimentar aplicado no estudo de alimentação de peixes. Boletim do Instituto Oceanográfico, 29: 205-207.

Keenleyside, M. H. A. 1991. Parental care. Pp. 191-208. In: Keenleyside, M. H. A., (Ed.). Cichlid Fishes: Behavior, ecology and evolutions. London, Chapman \& Hall, 377p.

Loebmann, D. \& J. P. Vieira. 2005. Distribuição espacial das assembleias de peixes na Lagoa do Peixe, RS, Brasil. Revista Brasileira de Zoologia, 22: 667-675.

Loureiro-Crippa, V. E. \& N. S. Hahn. 2006. Use of food resources by the fish fauna of a small reservoir (rio Jordão, Brazil) before and shortly after its filling. Neotropical Ichthyology, 4: 357-362.
Mazzoni, R. \& L. D. S. Costa. 2007. Feeding ecology of streamdwelling fishes from a coastal stream in the southeast of Brazil. Brazilian Archives of Biology and Technology, 50: 627-635.

Meijide, F. J., F. L. Nostro \& G. A. Guerrero. 2005. Gonadal development and sex differentiation in the cichlid fish Cichlasoma dimerus (Teleostei, Perciformes): A light - and electronmicroscopic study. Journal of Morphology, 264: 191-210.

Meschiatti, A. J. 1995. Alimentação da comunidade de peixes de uma lagoa marginal do rio Mogi-Guaçu, SP. Acta Limnologica Brasiliensia, 7: 115-137.

Motta Marques, D., C. Tucci, D. Calazans, V. L. M. Callegaro \& A. Villanueva. 2002. O Sistema Hidrológico do Taim - site 7. Pp. 125-144. In: Seeliger, U., C. V. Cordazzo \& F. Barbosa (Eds.). Os sites e o programa Brasileiro de pesquisas ecológicas de longa duração. Belo Horizonte, MCT-CNPq, 184p.

Nomura, H. \& S. C. Carvalho. 1972. Biologia e número de rastros do acará, Geophagus brasiliensis (Quoy \& Gaimard, 1824) (Pisces, Cichlidae). Revista Brasileira de Biologia, 32: 169-176.

Oliveira, D. C. \& S. T. Bennemann. 2005. Ictiofauna, recursos alimentares e relações com as interferências antrópicas em um riacho urbano no sul do Brasil. Biota Neotropica, 5: 1-13.

Ruppert, E. E., R. S. Fox \& R. D. Barnes. 2003. Invertebrate zoology: a functional evolutionary approach, seventh edition. Belmont, CA, Thomson Brooks/Cole, 1008p.

Sabino, J. \& R. M. C. Castro. 1990. Alimentação, período de atividade e distribuição espacial dos peixes de um riacho da Floresta Atlântica (sudeste do Brasil). Revista Brasileira de Biologia, 50: 23-36.

Seeliger, U. \& C. Odebrecht. 2010. O estuário da Lagoa dos Patos: um século de transformações. Rio Grande, Editora da Furg, 180p.

Thorp, J. H. \& A. P. Covich. 2001. Ecology and Classification of North American Freshwater Invertebrates, second edition. San Diego, Academic Press An Imprint of Elsevier, 1056p.

Uieda, V. S. 1983. Regime alimentar, distribuição espacial e temporal de peixes (Teleostei) em um riacho na região de Limeira, São Paulo. Unpublished Msc. Dissertation, Universidade Estadual de Campinas, Campinas, 151p.

Vinson, M. R. \& T. R. Angradi. 2011. Stomach emptiness in fishes: sources of variation and study design implications. Reviews in Fisheries Science, 19: 63-73.

Vono, V. \& F. A. R. Barbosa. 2001. Habitats and littoral zone fish community structure of two natural lakes in southeast Brazil. Environmental Biology of Fishes, 61: 371-379.

Voshell, J. R. 2002. A guide to common freshwater invertebrates of North America. Blacksburg, The McDonald \& Woodward Publishing Company, 442p.

Winemiller, K. O. 1989. Ontogenetic diet shifts and resource partitioning among piscivorous fishes in the Venezuelan llanos. Environmental Biology of Fishes, 26: 177-199.

Wootton, R. J. 1999. Ecology of teleost fish. London, Chapman and Hall, 404p.

Zar, J. H. 1994. Biostatistical analysis. 2a ed. New Jersey, Prentice Hall, 816p.

Submitted June 19, 2010

Resubmitted June 14, 2011

Accepted October 11, 2011

Published December 26, 2011 